\title{
Dietary Phospholipid
}

National Cancer Institute

\section{Source}

National Cancer Institute. Dietary Phospholipid. NCI Thesaurus. Code C68340.

Any substance found in the diet, comprising a glycerol backbone covalently bound to fatty acids in 2 positions, and to a phosphate group in the third position. Dietary phospholipids also include molecules derived physiologically from this basic structure. Fatty acid components of dietary phospholipids can be any of a broad variety found in nature. 